\title{
A second delivery after heart transplantation - a case study
}

\author{
Jarosław Kalinka ${ }^{1}$, Maria Szubert ${ }^{2}$, Andrzej Zdziennicki², Krzysztof Chojnowski ${ }^{3}$, Marek Maciejewski ${ }^{4}$, \\ Katarzyna Piestrzeniewicz ${ }^{4}$, Michał Zakliczyński ${ }^{5}$, Jarosław Drożdż \\ ${ }^{1}$ Department of Perinatology, First Chair of Gynecology and Obstetrics, Medical University of Lodz, Poland \\ 2Department of Surgical and Oncological Gynecology, Medical University of Lodz, Poland \\ ${ }^{3}$ Department of Hematology, Medical University of Lodz, Poland \\ ${ }^{4}$ Department of Cardiology, Chair of Cardiology and Cardiac Surgery, Medical University of Lodz, Poland \\ ${ }^{5}$ Chair and Clinical Department of Cardiac Surgery and Transplantation, Medical University of Silesia in Katowice, \\ Silesian Center for Heart Diseases, Zabrze, Poland
}

Kardiochirurgia i Torakochirurgia Polska 2014; 11 (3): 339-342

\begin{abstract}
Pregnancy after organ transplantation is becoming relatively common. We present the case of a heart transplant recipient who gave birth to a second child. Despite the fact that the transplanted heart seems to adapt well to the changes caused by pregnancy, gestation in patients after heart transplantation may be complicated by hypertension, pre-eclampsia, or preterm labor. In this article, we consider the issues of preterm uterine contractions, anemia, thrombocytopenia, and several other complications in pregnant patients with transplanted hearts. We also present current opinions regarding the use of glucocorticoids as a form of preventing breathing disorders in neonates as well as breast-feeding by mothers receiving immunosuppressive agents. Pregnancies in heart transplant recipients should be considered high-risk. A second successful delivery of a healthy child remains a challenge for such patients and their doctors.
\end{abstract}

Key words: heart transplantation, pregnancy, delivery, immunosuppressive agents.

\section{Introduction}

Heart transplantation has been used for the last three decades as a method of treating extreme heart failure. Women constitute one third of heart transplant recipients; approximately $20 \%$ of them are in reproductive age [1]. Pregnancy was contraindicated in women after heart transplantation during the 1990s; today, it is an increasingly common challenge for clinicians. Such pregnancy is always considered high-risk, as it is burdened with the risk of several typical complications [2]. We present the case of a 30-year-old patient, who, having

\section{Streszczenie}

Ciąża występuje w populacji pacjentek po przeszczepieniu ważnych życiowo narządów coraz częściej. W pracy zaprezentowano przypadek drugiego porodu u pacjentki po transplantacji serca. Przeszczepione serce dobrze adaptuje się do fizjologicznych zmian układu krążenia związanych z ciążą, niemniej ciąże u biorczyń serca częściej powikłane są nadciśnieniem tętniczym, stanami przedrzucawkowymi czy wystąpieniem porodu przedwczesnego. W artykule omówiono sposób postępowania w porodzie przedwczesnym, niedokrwistości, małopłytkowości oraz kilka innych zagadnień położniczych, takich jak podanie glikokortykosteroidów w profilaktyce zespołu zaburzeń oddychania u noworodków czy karmienie piersią przez kobiety leczone immunosupresyjnie. Ciąża u kobiety po przeszczepieniu serca powinna być zawsze traktowana jako ciąża wysokiego ryzyka. Wyzwaniem zarówno dla pacjentki po transplantacji serca, jak i prowadzącego lekarza jest urodzenie kolejnego zdrowego dziecka.

Słowa kluczowe: przeszczepienie serca, ciąża, poród, leczenie immunosupresyjne.

undergone a heart transplant due to hypertrophic cardiomyopathy, gave birth to two healthy children.

\section{Case study}

The 30-year-old patient was admitted to the Clinic of Perinatology of the Medical University of Łódź in the $34^{\text {th }}$ week of a third pregnancy due to a risk of premature labor and weak fetal movement.

Hypertrophic cardiomyopathy with left ventricular outflow tract obstruction was diagnosed in the described pa- 
tient as early as her first year of life. Taking the medical history of her family revealed that her mother and brother also suffered from hypertrophic cardiomyopathy; they, too, underwent heart transplantation. The initial symptoms were limited to reduced exercise tolerance and peripheral cyanosis. After many years of treatment with beta blockers and verapamil, during which she remained in NYHA functional class II, the patient's exercise capacity deteriorated between the age of 17 and 18, and she began to suffer from dyspnea at rest. The patient was included on the Poltransplant waiting list in 2002. A donor was found after a month, and a heart transplant procedure was conducted at the Silesian Center for Heart Diseases. Since that time, the patient has continued to receive immunosuppressive treatment; during the described (and the previous) pregnancy, it consisted in the administration of tacrolimus in monotherapy at the dose of $12 \mathrm{mg}$ until the $31^{\text {st }}$ week of pregnancy.

The patient's gynecological history revealed that she had been monitored for 1.5 years due to a hyperechogenic lesion in her right uterine appendages. In 2005, the patient underwent laparotomy and excision of the monitored lesion (histopathological diagnosis: cystis serosa ovarii dextrii). Before the pregnancy, the patient had a contraceptive intrauterine device for a period of 1.5 years. The described pregnancy was her third. In 2008, in the $39^{\text {th }}$ week of pregnancy, she gave birth by Caesarean section to a son, weighing $3150 \mathrm{~g}$, who was born in good general condition (Apgar score: 10). Performing a Caesarean section in this case had been suggested by the cardiologist after consultation with the obstetrician. In 2010, the patient's second pregnancy ended in a miscarriage during the $10^{\text {th }}$ week.

This was her third hospitalization during this pregnancy. Earlier, during the $16^{\text {th }}$ week, the gravida received conservative treatment at the hospital due to an obstetrical hemorrhage and a risk of miscarriage. In the $30^{\text {th }}$ week, the patient reported to the hospital due to premature contractions. Examinations were performed to confirm the wellbeing of the fetus (ultrasonography, cardiotocography); the gravida consulted a cardiac surgeon, and the next control fetal echocardiography was scheduled (the first examination, performed during the $22^{\text {nd }}$ week of pregnancy, showed no changes). In order to stimulate fetal lung growth, the patient received a course of steroids (two intramuscular $12 \mathrm{mg}$ doses of betamethasone in an interval of $24 \mathrm{~h}$ ), a hydroxyprogesterone preparation (administered intramuscularly), natural progesterone dosed at $2 \times 100 \mathrm{mg}$ (administered intravaginally), and magnesium supplementation with an oral preparation. Intravenous tocolytics were not employed, as the danger of premature labor receded quickly. The patient was discharged in good general condition in the $31^{\text {st }}$ week of pregnancy with the recommendation that she attend a follow-up examination at the Silesian Center for Heart Diseases in Zabrze. The follow-up examination, performed by a transplant specialist, revealed anemia and a rapid reduction of tacrolimus concentration in the blood. Two units of packed red blood cells were transfused, and the tacrolimus dose was increased to $20 \mathrm{mg}$ per day.
The patient was again admitted to our clinic during the $34^{\text {th }}$ week of pregnancy. At admission, the patient was in good general condition; circulation and respiration was normal, and there was no fever; however, the patient complained of irregular uterine contractions and dysuric symptoms. The employed diagnostic tools revealed a urinary tract infection (culture tests revealed S. epidermidis resistant to methicillin with a titer of $10^{5}$ ), anemia (Hb $10.0 \mathrm{~g} / \mathrm{dl}$ ), thrombocytopenia (68 thousand/ $\mu \mathrm{l}$ ), and symptoms indicating tacrolimus overdose: hyperkalemia $\left(\mathrm{K}^{+} 6.2 \mathrm{mmol} / \mathrm{l}\right)$; further examinations demonstrated a deterioration of renal function parameters (urea $43.8 \mathrm{mg}$ / $\mathrm{dl}$, creatinine $1.7 \mathrm{mmol} / \mathrm{l}$, minimal creatinine clearance rate $53.5 \mathrm{ml} / \mathrm{min}$ ). Tacrolimus concentration was shown to exceed the norm - $11 \mathrm{ng} / \mathrm{ml}$. The dose was lowered to $15 \mathrm{ng} / \mathrm{ml}$, and a therapeutic concentration was achieved. After hematological consultation, the diagnostic search was broadened: recent infections with parvovirus B19 and the HCV virus were excluded as causes of the hematologic disturbances; vitamin $B_{12}$ was supplemented (initial value: $92 \mathrm{pmol} / \mathrm{l}$, with the norm ranging from 156 to $672 \mathrm{pmol} / \mathrm{l}$ ). Echocardiography of the transplanted heart showed atrial and ventricular function and structural parameters that were typical of a long-term, good outcome of heart transplantation. Fetal ultrasound performed during the $34^{\text {th }}$ week of pregnancy revealed signs of an intrauterine growth restriction; the monitored flow in the umbilical artery was normal. In the $37^{\text {th }}$ week of pregnancy, the patient went into labor and gave birth by Caesarean section. Her newborn son weighed $2670 \mathrm{~g}$ and was in good general condition, without signs of growth restriction; he was, however, treated for congenital pneumonia. Based on the wishes of the postpartum mother, who was informed of the theoretical risk for the newborn associated with his mother's tacrolimus treatment, lactation was not inhibited.

\section{Discussion}

On average, 30 new female heart transplant recipients are registered every year in Poland. This report describes the case of a heart transplant recipient who gave birth to a second healthy child. Clinical practice with regard to pregnancy management in women after the transplantation of vital organs is mostly based on expert recommendations; there are no guidelines constructed on the basis of RCT studies due to the still small number of heart transplant recipients [2-5]. The considerations significant for obstetricians providing care to female heart transplant recipients include: providing reliable information concerning the influence of immunosuppressive treatment on the pregnancy, referring the patient at the appropriate time to a center performing prenatal diagnostics and fetal echocardiography, monitoring the patient with respect to pregnancy-induced hypertension, and cooperating with the attending cardiologist and transplant specialist in order to determine the optimal method of delivery [6-8]. During the 1990s, pregnancy was contraindicated for heart transplant recipients. The improvements in the cardiac surgical care provided to 
patients qualified for heart transplantation and during the postoperative period result in the improved well-being of women after the transplantation and their continued ability to procreate [9].

Currently, even though it is still difficult to unequivocally pinpoint the safest moment for conception, patients with transplanted hearts give birth to healthy children both by natural vaginal delivery and by Caesarean section. A heart transplant procedure in the patient's medical history is not in itself an indication for delivery by Caesarean section [10]. The described gravida was qualified for the first Caesarean section by the obstetric-cardiac team due to low height, high expected weight of the child, and the expected need for shortening the second stage of labor. Female heart transplant recipients desiring offspring must be informed of both the risks related to the influence of immunosuppressants on fetal development and the dangers associated with the high number of complications pertaining to the pregnancy and transplant $[5,11]$. Such complications include arterial hypertension, pre-eclampsia, infections (especially viral), and intrauterine growth restriction [3, 4]. If, before the pregnancy, the function of the transplanted heart had been normal, the physiological hemodynamic changes related to the pregnancy are usually well tolerated. Unassisted discontinuation of immunosuppressive medication during pregnancy may lead to transplant rejection [12]. Changes in the body's immune response associated with the pregnancy may result in the development of antibodies in the HLA system, whose presence may lead to the loss of the transplanted organ [13].

Immunosuppressive agents must be administered during the pregnancy, even though most of them belong to category $C$ in terms of their safety of use in pregnant women according to the Food and Drug Administration (FDA). The best known agents include glucocorticoids, azathioprine, ciclosporin, tacrolimus, and mycophenolate mofetil. After the use of tacrolimus, transient perinatal hyperkalemia and hyperglycemia have been observed [14]. Treatment with azathioprine, tacrolimus, glucocorticoids, and ciclosporin is allowed in pregnant women [15-17]. One should remember to monitor the concentrations of ciclosporin and tacrolimus in the blood of the gravida - the need for these agents during pregnancy rises, and various clinical situations, e.g. anemia or concurrent therapy with agents inhibiting the enzymes of hepatic cytochromes, may require adjustment of the dose. During the perinatal period, we monitored the concentrations of tacrolimus as often as every 2 days. Of particular note is the relationship between the hematocrit levels in blood morphology and the exposure to ciclosporin or tacrolimus, which are transported primarily by erythrocytes. In anemic conditions, achieving a therapeutic concentration of each of these agents requires large oral doses, but one should remember that transfusing red blood cells will result in a rapid elevation of agent concentration, which may cause acute kidney injury or even an onset of convulsions [18].

In the case of tacrolimus or ciclosporin monotherapy, folic acid supplementation during the first trimester should be conducted in accordance with the generally accepted guidelines. Mycophenolate mofetil and sirolimus should be discontinued approximately 6 weeks before a planned pregnancy due to the risk of fatal congenital defects in the fetus [19].

Breastfeeding is not recommended to women undergoing chronic immunosuppressive treatment [20]. However, considering tacrolimus used in monotherapy, the concentration of the agent in milk is very low, and the newborn is exposed to approximately $0.5 \%$ of the tacrolimus concentration in the mother's blood [21]. Unfortunately, the manufacturer's guidelines indicate that lactation should be inhibited in women receiving the agent; therefore, decisions concerning breastfeeding (as was the case with our patient) should be documented with an appropriate written consent form. The postpartum mother described in this article continues to breastfeed, and the neonate shows no signs of side effects.

The successful outcome of this case - the birth of a second healthy child by a heart transplant recipient - can be attributed to the involvement of an interdisciplinary team and numerous specialists as well as good cooperation with the patient.

\section{Disclosure}

Authors report no conflict of interest.

\section{References}

1. Sterkowicz S. Historia medycyny. Czterdzieści lat później. Transplantacja serca - wczoraj, dziś i jutro. Kardiochir Torakochir Pol 2007; 4: 423-427.

2. Kirk EP. Organ transplantation and pregnancy: a case report and review. Am J Obstet Gynecol 1991; 164: 1629-1634.

3. Bordignon S, Aramayo AM, Nunes e Silva D, Gründler C, Nesralla I. Pregnancy after cardiac transplantation. report of one case and review. Arq Bras Cardiol 2000; 75: 515-522.

4. Migdał M, Kołodziejski L, Wolak J, Chałupczak P, Garlicki M, Klimek M, Tomaszczyk J. Opis dwóch przypadków ciąży zakończonej sukcesem u kobiet po przeszczepie serca. Gin Prakt 2003; 11: 36-38

5. Miniero R, Tardivo I, Centofanti P, Goggi C, Mammana C, Parisi F, Dall'Omo AM. Pregnancy in heart transplant recipients. J Heart Lung Transplant 2004; 23: 898-901.

6. Dubiel J, Surdacki A, Bednarz B et al. Niewydolność serca. Leczenie operacyjne przewlekłej niewydolności serca. In: Szczeklik A (ed.). Choroby wewnętrzne. Medycyna Praktyczna, Kraków 2005; 332-333.

7. Guba M, Graeb C, Jauch KW, Geissler EK. Pro- and anti-cancer effects of immunosuppressive agents used in organ transplantation. Transplantation 2004; 77: 1777-1782.

8. Serwacka A, Rydzewski A. Nowotwory przewodu pokarmowego u pacjentów po transplantacji nerki. Prz Gastroenterol 2006; 1: 197-201.

9. Zembala M. Rethinking EuroSCORE - how can we redefine surgical risk to diminish intraoperative complications. Kardiol Pol 2010; 68: 130.

10. Cowan SW, Davison JM, Doria C, Moritz MJ, Armenti VT. Pregnancy after cardiac transplantation. Cardiol Clin 2012; 30: 441-452.

11. Sibanda N, Briggs JD, Davison JM, Johnson RJ, Rudge CJ. Pregnancy after organ transplantation: a report from the UK Transplant pregnancy registry. Transplantation 2007; 83: 1301-1307

12. Fusch KM, Coustan DR. Immunosuppresant therapy in pregnant organ transplant recipient. Semin Perinatol 2007; 31: 363-371.

13. Ginwalla M, Pando MJ, Khush KK. Pregnancy-related human leukocyte antigen sensitization leading to cardiac allograft vasculopathy and graft failure in a heart transplant recipient: a case report. Transplant Proc 2013; 45: 800-802.

14. Kainz A, Harabacz I, Cowlirck IS, Gadgil SD, Hagiwara D. Review of the course and outcome of 100 pregnancies in 84 women treated with tacrolimus. Transplantation 2000; 70: 1718-1721.

15. Park-Wyllie L, Mazzotta P, Pastuszak A, Moretti ME, Beique L, Hunnisett L, Friesen MH, Jacobson S, Kasapinovic S, Chang D, Diav-Citrin O, Chitayat D, 
Nulman I, Einarson TR, Koren G. Birth defects after maternal exposure to corticosteroids: prospective cohort study and meta-analysis of epidemiological studies. Teratology 2000; 62: 385-392.

16. Gutkowski K, Kamińska E, Gutkowska D. Leczenie immunosupresyjne w ciąży - możliwości i ograniczenia. Gin Prakt 2008; 3: 28-34.

17. Bar Oz B, Hackman R, Einarson T, Koren G. Pregnancy outcome after cyclosporine therapy during pregnancy: a meta-analysis. Transplantation 2001; 71: 1051-1055.

18. Zakliczyński M. Ciąża u kobiety po przeszczepieniu serca. W: Ciąża - problemy internisty i kardiologa. Dłużniewski M, Grzywanowska-Łaniewska I, Wielgoś M (eds.). Czelej, Lublin 2012; 97-102.
19. Schoner K, Steinhard J, Figiel J, Rehder H. Severe facial clefts in acrofacial dysostosis: a consequence of prenatal exposure to mycophenolate mofetil? Obstet Gynecol 2008; 111: 483-436.

20. Rekomendacje PTG w sprawie antykoncepcji. Ginekologia po Dyplomie; wyd. specjalne, luty 2008; 10: 233-235.

21. Gardiner SJ, Begg EJ. Breastfeeding during tacrolimus therapy. Obstet Gynecol 2006; 107: 453-455 